in research bearing upon it, at an early stage in the student's career. The subject of the essay was "The Relative Importance of Nature and Nurture in the Development of Psychiatric Disorder'. In addition to the Travelling Fellowship, three cash prizes have been awarded : $£ 100$ to Dr. G. Sedman, Manchester Victoria Memorial Jewish Hospital; $£ 50$ to $\mathrm{Mr}$. J. D. Swales, Westminster Medical School ; and $£ 25$ to Mr. A. P. K. John, Pembroke College, Oxford.

\section{Institution of Civil Engineers}

THE following were recently elected to office in the Institution of Civil Engineers: President, Prof. A. J. S. Pippard; Vice-Presidents, A. C. Hartley, Sir Herbert Manzoni, Sir George McNaughton, R. W. Mountain; New Members of Council, L. Carnie (Glasgow and West of Scotland), N. S. Cox (South Western), A. Dean, S. E. Faber (Colonies), J. R. Farquharson (Colonies), J. T. D. Firth (North Western), O. Holden (Canada), W. P. F. McLaren (South Africa), T. P. de S. Munasinghe (Ceylon), R. H. Roberts (Northern and Southern Rhodesia), J. F. Stanbury, R. W. Taylor (Colonies).

\section{University News : The Queen's University, Belfast}

THE following appointments have recently been made in the Queen's University of Belfast: Dr. G. Seth, to the chair of psychology ; Dr. H. G. Heal, to a lectureship in inorganic chemistry; Mr. T. K. Marshall, to a lectureship in pathology (forensic medicine).

Birmingham

THE following appointments in the University of Birmingham have recently been announced: Prof. D. L. Linton, professor of geography in the University of Sheffield, to the chair of geography, made vacant by the retirement of Prof. R. H. Kinvig, from October 1; Dr. P. J. Hilton, senior lecturer in mathematics in the University of Manchester, to the Mason chair of pure mathematics, made vacant by the resignation of Prof. C. A. Rogers, from October I; Mr. I. T. S. Essery, to be senior lecturer in civil engineering; Mr. D. M. G. Wishart, to be lecturer in statistics in the Department of Pure Mathematics; Dr. J. D. Young, to be lecturer in physics ; Drs. K. J. Morgan, R. S. Lehrle and J. D. Hobson, to be lecturers in chemistry; Dr. R. E. Smallman, to be lecturer in physical metallurgy; Mr. G. R. Coope, to be lecturer in geology; and Mr. N. Dennis, to be lecturer in sociology. The title of reader in mathematical physics has been conferred on Dr. G. E. Brown, lecturer in mathematical physics, from October 1.

Bristol

THE following appointments in the University of Bristol have recently been announced: Mr. J. M. Cook, reader in classical archæology in the University, to a chair of ancient history and classical archæology; Dr. J. W. F. McOmie, to a readership in organic chemistry; Mr. R. W. Marsh, to a readership in plant pathology; Dr. Suzanne K. R. Clarke, to a lectureship in bacteriology.

London

THe title of professor of pure mathematics in the University of London has been conferred on Dr. K. A. Hirsch, and that of professor of zoology on Dr. G. E. Newell, in respect of their posts at Queen
Mary College. The following University appoint. ments have also been made: Mr. A. Stuart, to the readership in statistics tenable at the London School of Economics and Political Science; and Dr. E. Cotchin, to the readership in veterinary pathology at the Royal Veterinary College.

\section{Announcements}

THe Société Mycologique de France and the British Mycological Society are holding a joint foray at Reading during September 3-10. Further information can be obtained from Dr. F. B. Hora, The University, Reading, Berks.

A symposrum on "Salinity Problems in the Arid Zones", organized by Unesco, will be held in Teheran during October 11-15. Further information can be obtained from M. Batisse, Arid Zone Unit, Department of Natural Sciences, Unesco, 19 Avenue Kléber, Paris XVIe

THE annual conference of Aslib will be held at the University of Nottingham during September 5-8. Members are requested to register not later than August 22. Further information can be obtained from Aslib, 3 Belgrave Square, London, S.W.1.

The Institute of Rural Life at Home and Overseas is holding a course of rural studies at the Essex Institute of Agriculture, Writtle, near Chelmsford, Essex, during August 31-September 13. Further information can be obtained from the Institute, 159 Bryanston Street, Marble Arch, London, W.1.

THE inaugural general meeting of the Gas Chromatography Discussion Group and an informal symposium will be held in the Chemistry Department, University College, Gower Street, London, W.C.1, on September 23. Further information can be obtained from Dr. D. Ambrose, Chemical Research Laboratory, D.S.I.R., Teddington, Middlesex.

A general discussion on "Ions of the Transition Elements", organized by the Faraday Society, will be held in Dublin during September 9-11. There will be two sessions, devoted respectively to optical and magnetic properties, and to the energeties of complexes. It is hoped to circulate advance proofs of the papers to be read. Further information can be obtained from the Assistant Secretary, Faraday Society, 6 Gray's Inn Square, London, W.C.1.

THE twenty-seventh general meeting of the Society for General Microbiology will be held in the University of Liverpool on September 18 and 19. Those wishing to present papers, films or demonstrations should send the titles to Dr. B. W. Lacey not later than July 28. An informal meeting of those interested in animal viruses will be held on September 18. Further information can be obtained from Dr. B. W. Lacey, Department of Bacteriology, Westminster Medical School, London, S.W.1.

A Summer School, organized by the Universities Federation for Animal Welfare, is to be held at Culham College, Abingdon, Berkshire, during September 13-20. The programme will include lectures on various aspects of animal welfare, animal hus. bandry, humane technique in the laboratory, and related international problems. The fee, including full board, is $£ 7$, with a special reduced fee of $£ 4$ for students. All inquiries and applications to attend should be addressed to Miss M. P. Williams, Universities Federation for Animal Welfare, $7 a$ Lamb's Conduit Passage, London, W.C.1. 